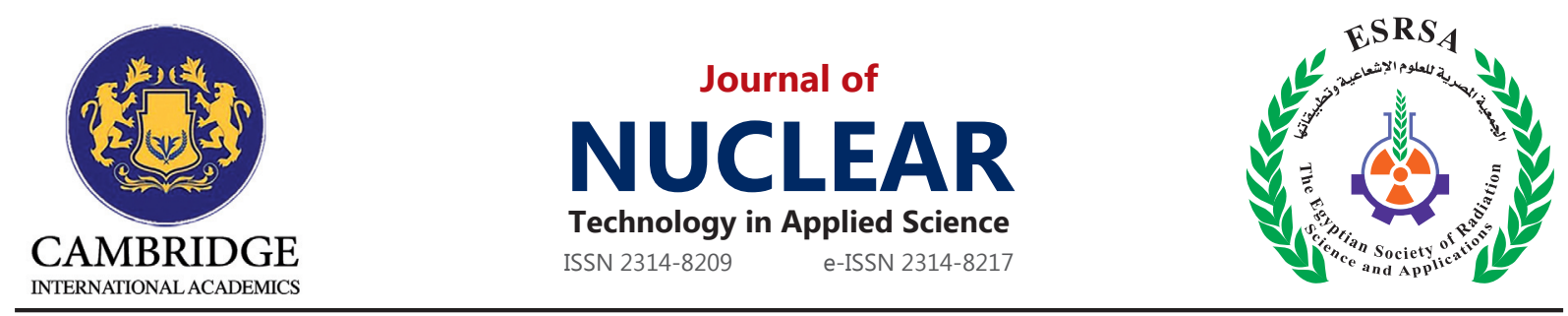

J. Nucl. Tech. Appl. Sci., Vol. 6, No. 2, PP. 107 : 114 (2018)

\title{
Steady State Thermal Hydraulic Model for PWR Light Water Reactors
}

\author{
El-sheikh, B.M
}

Received: 03/05/2018

Accepted: 14/06/2018

E.mail:badawymel@yahoo.com

\section{ABSTRACT}

Thermal-hydraulic analysis of nuclear reactors is very important to predict the temperature distribution in the reactor core elements, such as fuel cladding and fuel rods. Power reactors cores are composed of cylindrical fuel rods that contain fuel pellets, gap and cladding. Our goal will be to calculate the fuel and coolant temperature distribution and pressure gradient in an average and hot channel and others safety limits.

The present paper introduces a simple one dimensional Fortran program called PWRTH for steady state Thermal Hydraulic (TH) calculations and fuel elements heat conduction for Pressurized Water Reactors. A parametric analysis for obtaining the maximum possible reactor power respecting safety limits is performed.

\section{KEYWORDS}

Power Reactors;

Thermal hydraulic;

Safety limits.

1. Egyptian Nuclear and Radiological Regulatory Authority, Cairo, Egypt. 


\section{INTRODUCTION}

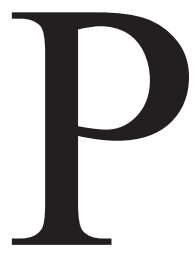

ressurized water reactors (PWRs) constitute the large majority of the world's nuclear power plants and are one of three types of light water reactor (LWR). Two things are characteristic for the pressurized water reactor (PWR) when compared with other reactor types: coolant loop separation from the steam system and pressure inside the primary coolant loop. The pressure in the primary coolant loop is typically 15-16 mega pascals (150-160 bar), which is notably higher than in other nuclear reactors. Light water is used as the primary coolant in a PWR. The pressurized water reactor has three new Generation III reactor evolutionary designs: the AP-1000, VVER-1200, ACPR1000+.

The modular modeling of the plant components is used to develop a system model and perform the simulation. Theoretical models of the components are obtained by formulating the describing differential or algebraic equations, usually derived from conservation of mass, energy, and momentum relationships. Accurate design and measurement data are used to determine the model parameters and inputs.

This thermal feedback requires the solution of the non-linear heat transfer equation in the fuel rods, to retrieve the effective temperature of heavy nuclei observed by the coming neutrons (Rowlands, 1962; de Kruijf, 1994 \& Goltsev et al., 2003). In the heat transfer equation, non-linearity arises with the dependence of the physical properties on the unknown temperature, and with possible radiative sources. Different forms of heat transfer needs as well specific physical properties, being thermal conductivities, contact resistances, specific heat coefficients, mass densities, radiative emissivities and others (Carslaw and Jaeger,J. 1986 \& Tomatis, D., 2013).

PWRTH is a program that perform steady state thermal hydraulic PWR core calculations and heat conduction with the capability of calculating the required safety parameters like the Departure from Nucleate Boiling DNB, and the Fuel limit FL.

\section{THERMAL HYDRAULIC AND HEAT TRANSFER MODELING}

\section{Discretization of the fuel rod}

The fuel rod will be divided into nodes. Nodalization of fuel rod is radially and axially. In axial direction, the fuel is divided into ten slices. The radial discretisation the rod covers four nodes in the fuel, one node in gap, and two nodes in the cladding as shown in Fig. 1.

The physical properties, such as thermal conductivity and specific heat, are all temperature dependent.

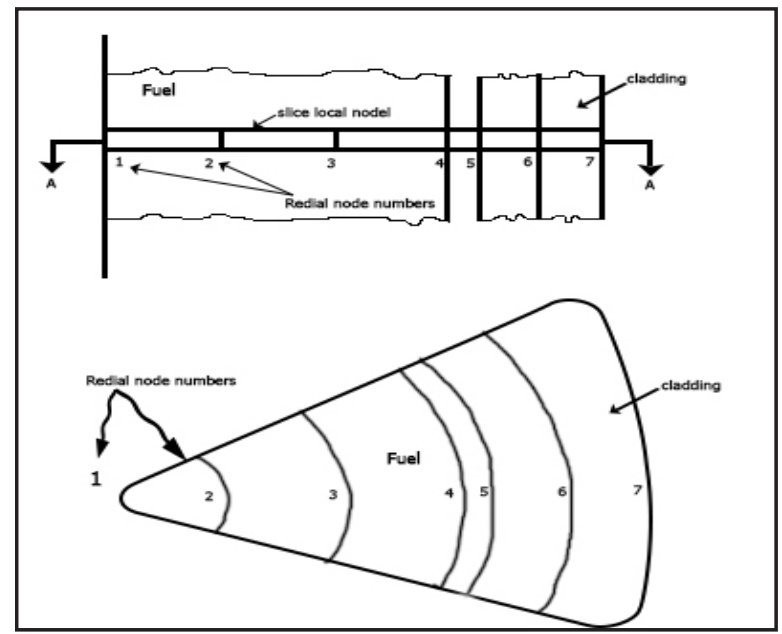

Fig. (1): Radial fuel rod discretisation.

The heat flux and Temperature distribution in the axial direction

The amount of heat generated along the fuel channel follows the neutron flux and fission reaction distribution along the fuel channel. The natural axial variation of the neutron flux is given by the following relation (Nikola K. and Popov, 2015 ):

$$
\varphi(z)=\varphi_{\max } \cos \left(\frac{\pi z}{L_{\varepsilon}}\right),
$$

Where Le is the effective fuel length and $\varphi_{\max }$ is the maximum neutron flux in the middle core. 
In coordinate system, the power distribution can be expressed by the following equation:

$$
q^{\prime \prime}(z)=\left(q^{\prime \prime}\right)_{\max } \sin \left(\frac{\pi z}{L_{\varepsilon}}\right)
$$

Where $\left(q^{-}\right)_{\max }$ is the surface heat flux at the middle of the fuel rod in the axial direction.

In a steady-state situation, the sensible heat gain by the passing coolant (assuming no phase change) is equal to the heat generated in the differential fuel rod ( $\mathrm{Cp}$ is the specific heat capacity at a given pressure $[\mathrm{kJ} / \mathrm{kg} \mathrm{oC}])$ :

$w c_{p} \int_{T_{f 1}}^{T_{f}} d T_{c}=\left(q^{-\prime}\right)_{\max } \int_{z=0}^{Z=L} \sin \left[\frac{\pi z}{L_{\varepsilon}}\right] d z$,

The axial variation of the fluid temperature Tc can be obtained by substituting Eq. (2) into Eq. (3) and integrating (El-Wakil ,M.M.,1978):

$T_{c}=T_{c, i n}+\frac{\left(\left(q^{-}\right)_{\max }\right) L_{\varepsilon}}{\pi w c_{p}}\left[1-\cos \left[\frac{\pi z}{L_{\varepsilon}}\right]\right]$

The subscript "in" designates the entry point in the fuel meat. In this equation, the equivalent core length is approximated by the actual core length, i.e $\mathrm{L}=L_{\theta}$

The coolant temperature is measured in the middle of the fuel $\operatorname{rod}$ for $z=L / 2$ and has the following form:

$T_{c, \text { mid }}=T_{c, \text { in }}+\frac{\left(q^{-}\right)_{\max } A_{f} L}{\pi w c_{p}}$,

\section{Heat transfer coefficient correlation}

For the heat transfer coefficient, the DittusBoelter correlation were implemented (Dittus, F. W, and Boelter ,L.M. K, 1930,1985),( Winterton , R. H. S., 1998):

$h=0.0023\left[\frac{\dot{m} \cdot D_{h}}{\mu \cdot A}\right]^{0.8}\left[\frac{\mu \cdot c_{p a}}{k_{a}}\right]^{0.4} \frac{k_{a}}{D_{h}}$

Where $\mathrm{h}$ is the heat transfer coefficient, the $\dot{m} \dot{m}$ and $\mu$ are the mass flow and viscosity of the coolant in $\mathrm{kg} / \mathrm{s}$, respectively, $D_{h}$ is the hydraulic diameter in $m$, $C_{p a}$ is the specific heat at constant pressure in $J / \mathrm{kg} . o \mathrm{C}$ and $k_{a}$ is the thermal conductivity of water in $W / m . o C$.

\section{Radial heat conduction in the fuel meat}

The (time independent ) conduction equation for an infinite cylindrical fuel pin (Anglart , H. , 2010):

$-\frac{1}{r} \frac{d}{d r}\left[\lambda r \frac{d T}{d r}\right]=\dddot{q}$,

After integration of Eq. (7) and applying the boundary conditions, the solution in each region (centerline, fuel gap, gap-clad, clad-fluid boundary) is found.

\section{Pressure distribution in channels with single phase flow}

The total pressure drop over the coolant circulation loop has to be known in order to determine the needed pumping power.

The pressure gradient along an arbitrary channel with constant cross-section $\mathrm{A}(\mathrm{z})$ and with mass flux $\mathrm{G}$ can be represented by the following equation (Anglart , H., 2005) :

$-\frac{d p}{d z}=\frac{1}{A} \frac{d}{d z}\left(\frac{G^{2}}{\rho} A\right)+\frac{p}{A} \frac{d A}{d z}+\frac{P_{w} \tau_{w}}{A}+\rho g \sin \varphi$

Where $\tau_{w}$ is wall shear stress, $P_{w}$ watted channel perimter, $\rho$ is the coolant density .

For a vertical channel $\left(\varphi=90^{\circ}\right)$ with constant cross-section (assumption valid for most of LWR fuel assemblies, Eq. ( 8) becomes,

$-\frac{d p}{d z}=\frac{P_{w} \tau_{w}}{A}+\rho g$

For vertical channel with length $L$, the last equation can be integrated from $\mathrm{z}=0$ to $\mathrm{z}=\mathrm{L}$ to obtain the total pressure drop between the inlet and the outlet of fuel assembly:

$-\Delta p_{\text {tot }}=-\int_{0}^{l} \frac{d p}{d z} d z=-[p(L)-p(0)]$
$-[p(L)-p(0)]=\frac{p_{w} \tau_{w}}{A} L+\rho g L$

As can be seen, the total pressure drop consists of two terms: the friction loss term and gravity term.

Where: $-\left[\frac{d p}{d z}\right]_{\text {fric }}=C_{f} \frac{P_{w}}{A} \cdot \frac{G^{2}}{2 \rho}$

Where the friction coefficient for laminar flow 
can be written in a general form as,

$C_{f=a \cdot R e^{-b}}$

Where $\mathrm{a}$ and $\mathrm{b}$ are constant.

\section{Departure from Nucleate Boiling (DNB)}

The heat flux to cause DNB depends on $T_{b}$, $\mathrm{G}$, and $\mathrm{P} \rightarrow \overline{\bar{q}}\left(T_{b}, G, P\right)$

$\operatorname{DNBR}(\mathrm{z})=\frac{\overline{\bar{q}}_{D N B}}{\overline{\bar{q}}}$

Where $T_{b}$ is the bulk temperature.

$\mathrm{MDNBR} \equiv \min . \mathrm{DNBR}>1.3$.

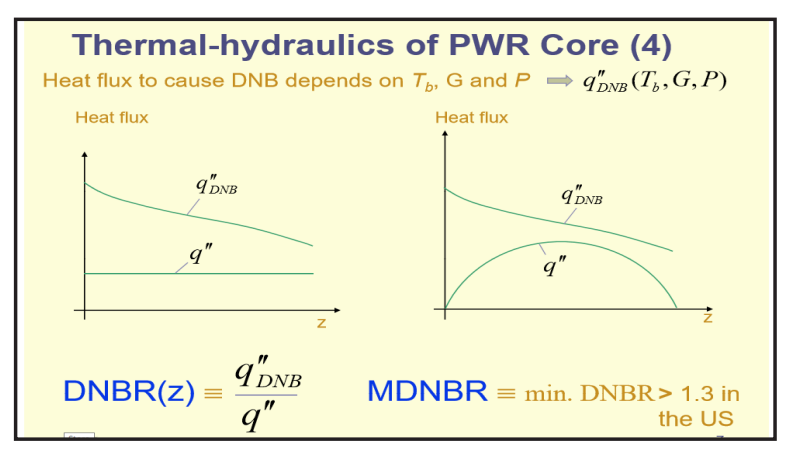

Fig. (2): Typical relation shapes of heat flux and $\overline{\bar{q}}_{D N B}$ distribution along the fuel axis.

The calculation of $\overline{\bar{q}}_{D N B}$ in program was according to the Tong 68 correlation [Buongiorno, J.,2010 ]
$\overline{\bar{q}}_{D N B}=K_{\text {Tong }} \frac{G^{-4} \mu_{f^{-6}} h_{f g}}{D_{\varepsilon}^{-6}}$

Where :

$K_{\text {Tong }}=\left\lfloor 1.76-7.433 x_{\theta}+12.222 x_{\theta}^{2}\right\rfloor$

$x_{\theta}=\frac{C_{P_{l} l}\left(T_{\text {sat }}-T_{b}\right)}{h_{f g}}<0$ in PWR

\section{RESULTS}

For typical PWR data tabulated in Table .1, axial power density, fuel rod central temperature , cladding temperatures, radial temperature profile in fuel rod and the temperature distribution throughout the coolant when the simulation has reached a steady state in Figures : 3, 4, 5, 6, 7, respectively. And to test the safety parameter we drow the effects of changing reactor power to upper and lower than the typical reactor power (1940 MWT) on fuel temperature and DNBR as in Figures 8 to 11.

It is found that if we respect the maximum fuel temperature $(15000 \mathrm{C})$, the maximum allowed reactor power will be $\sim 2390 \mathrm{MW}$. For DNBR two limits are presented in literature: 1.3 and 1.17. If we consider 1.3 the maximum power is $1940 \mathrm{MW}$, if we consider 1.17 the maximum power is $\sim 2250 \mathrm{MW}$.

Table (1) : Screening of fungi for tri-calcium phosphate solubilization [Positive means halo zone formation around the colony].

\begin{tabular}{|c|c|}
\hline Reactor Power $(\mathrm{P})$ & $1940 \mathrm{MWt}$ \\
\hline Core height [m] & 3.658 \\
\hline Fuel rod radius [m] & $4.75 \mathrm{E}-03$ \\
\hline Clad thik [m] & $0.57 \mathrm{E}-03$ \\
\hline Gap thik. [m] & $7.87 \mathrm{E}-05$ \\
\hline No. fuel elements & 145 \\
\hline No. of rod in fuel elements & 264 \\
\hline Inlet core temperature [k] & 552.5 \\
\hline Outlet core temperature $[\mathrm{k}]$ & 588.6 \\
\hline P1 & $2300 \mathrm{MWt}$ \\
\hline P2 & $2800 \mathrm{MWt}$ \\
\hline P3 & $1500 \mathrm{MWt}$ \\
\hline P4 & $1100 \mathrm{MWt}$ \\
\hline
\end{tabular}



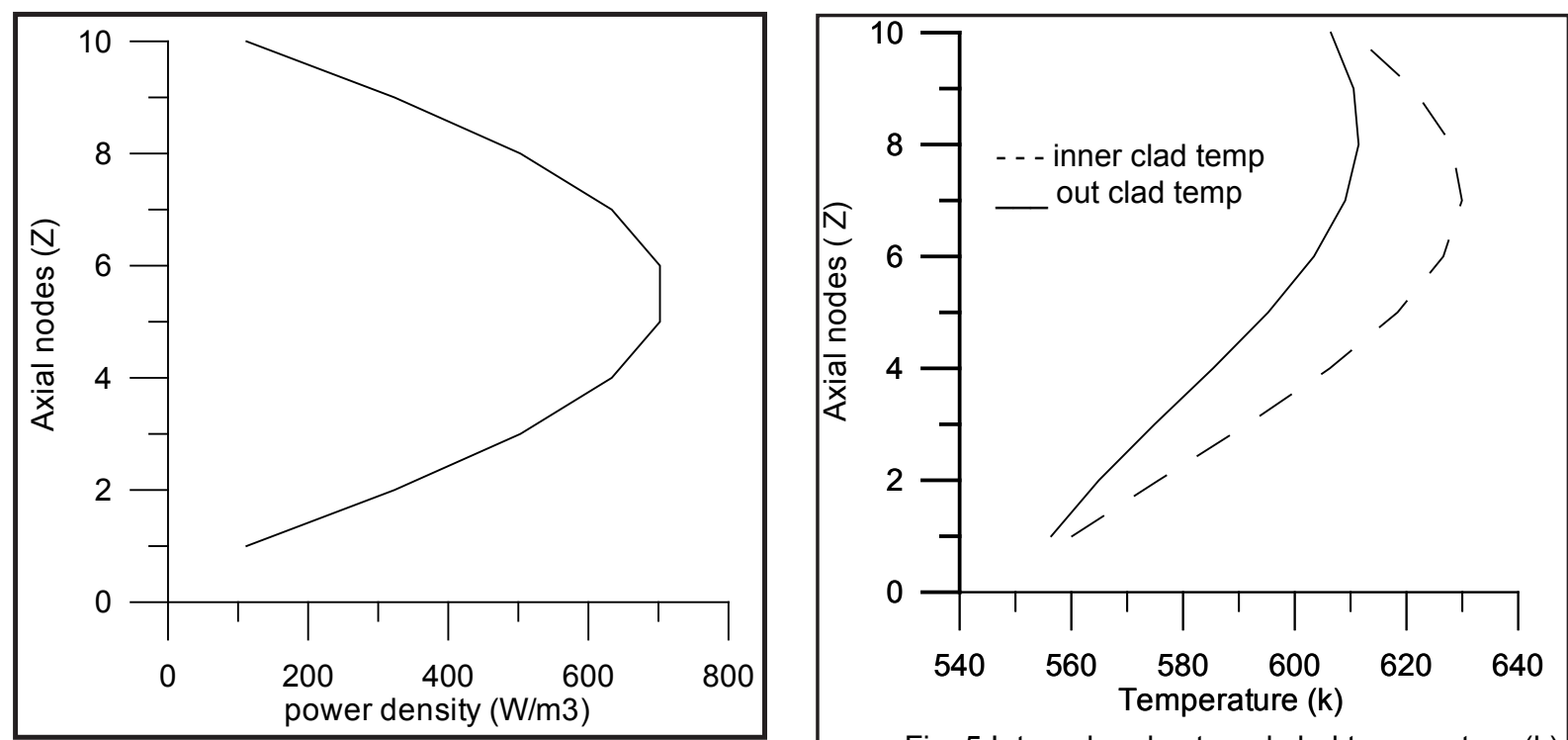

Fig. (3): Axial power density distribution.
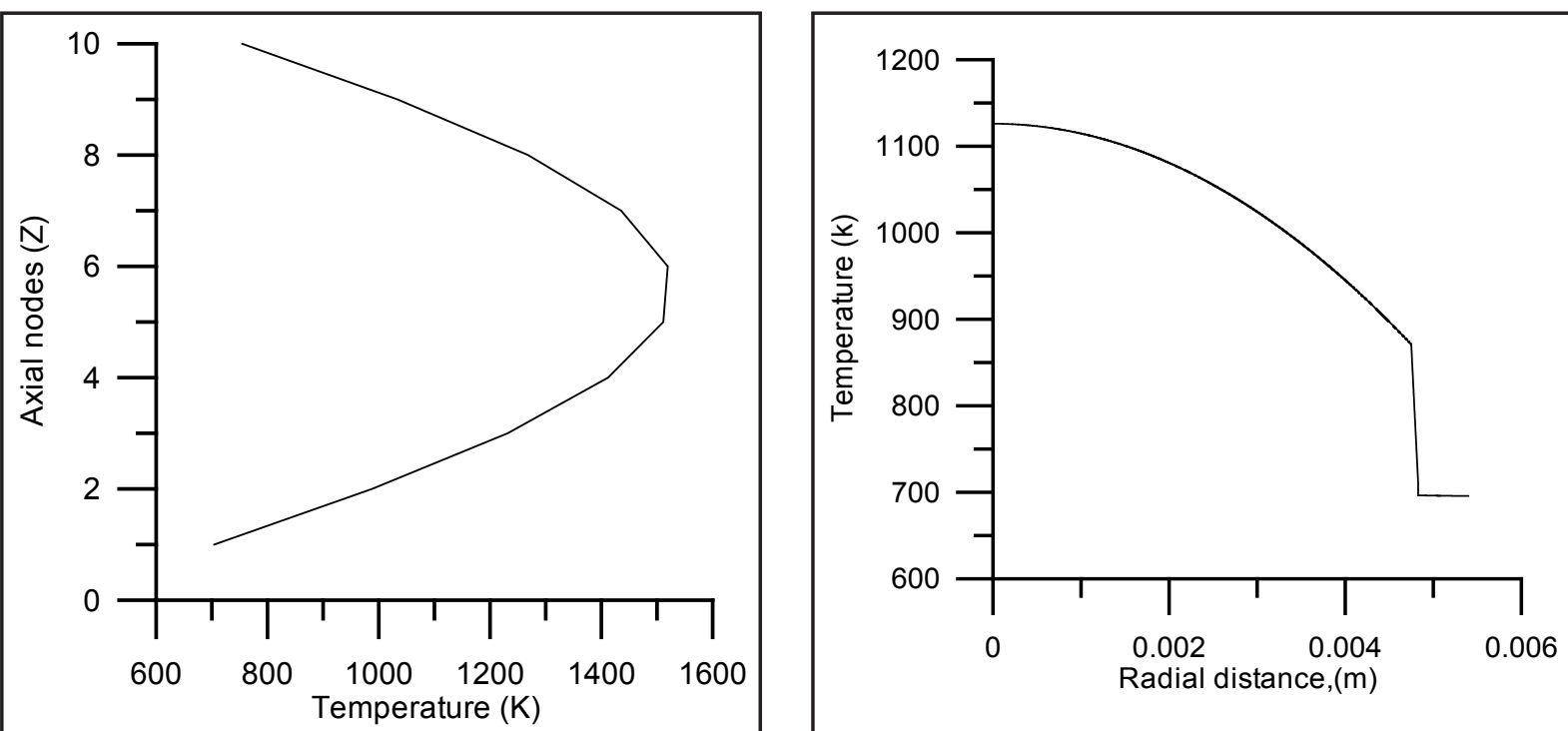

Fig. 4 Fuel rod centeral temperature (k) 


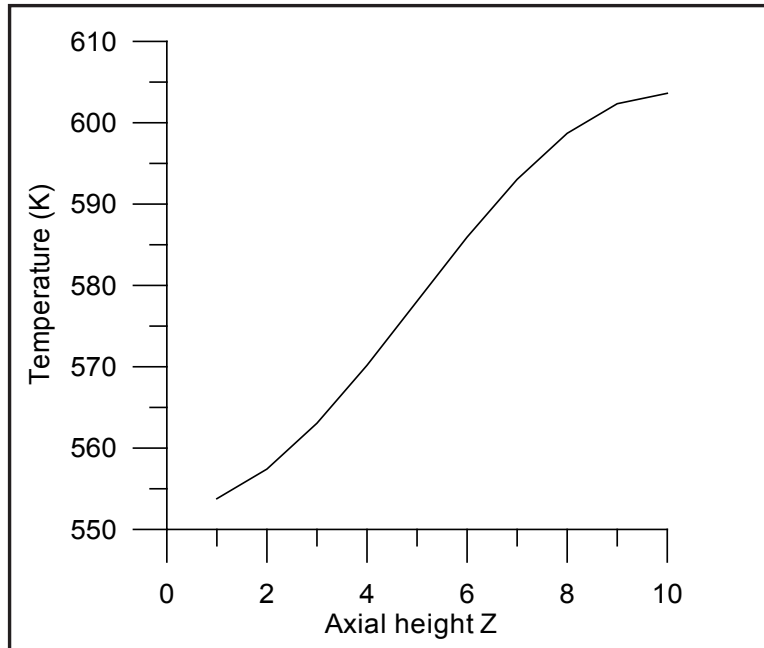

Fig. 7 : Temperature distribution along the coolant channel

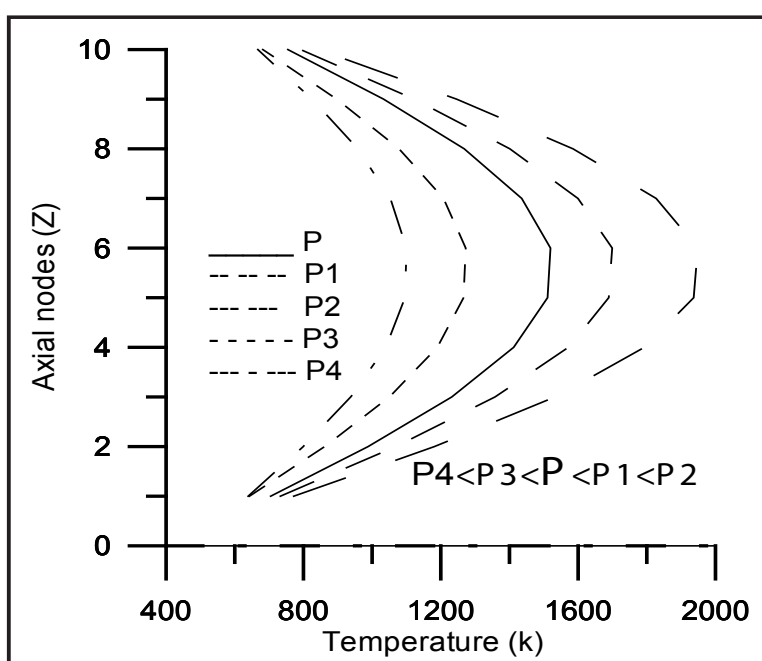

Fig. (8): Change of fuel central temperature according to changing Reactor power

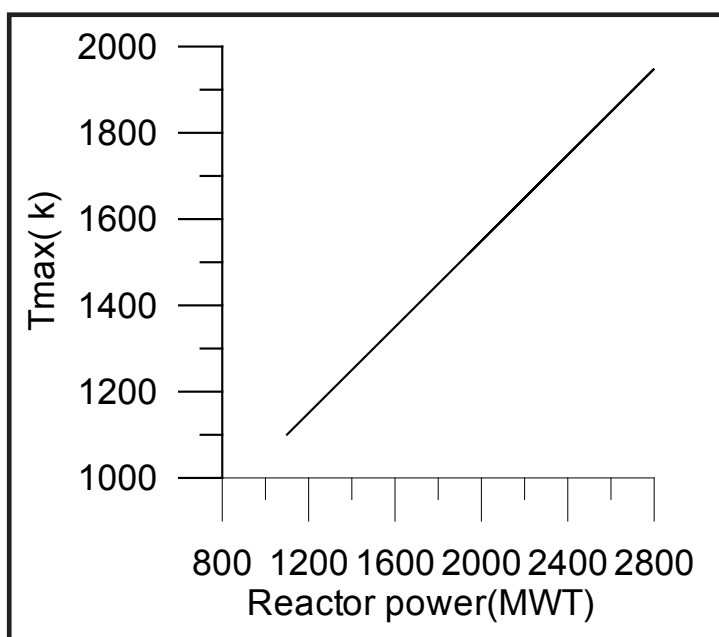

Fig. (9): Fuel rod central temperature versus different reactor power

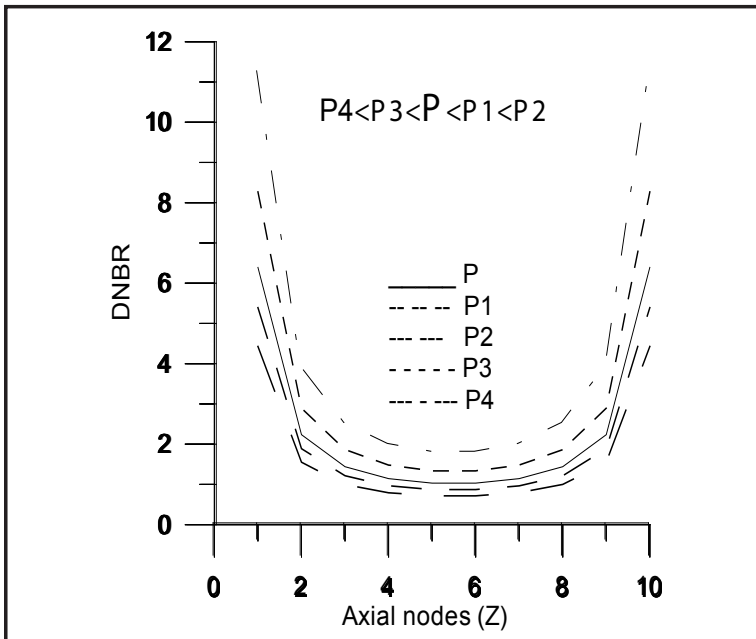

Fig. (10): Change of DNBR according to changing of reactor power

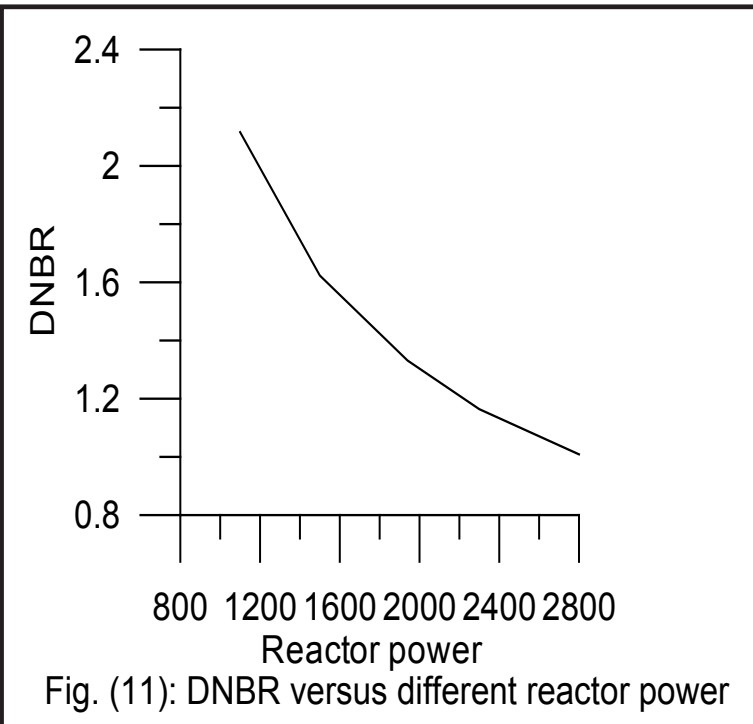

\section{CONCLUSIONS}

PWRTH a Fortran program has been designed for PWR thermal hydraulic. Heat transfer radially and vertically in average and hot channel are presented. Some thermal hydraulic limits are presented. The results has shown that the program to be already an effective tool for PWR thermal hydraulic analysis. It's found that the max. allowable power for fuel temperature is $2390 \mathrm{MW}$ and the max. allowable for two DNBR limits 1.3, 1.17 are $1940 \mathrm{MW}$ and 2250 MW respectively. Hence it is shown that the DNBR is the governing factor in determining the maximum operating power. 


\section{ACKNOWLEDGEMENT}

I wish to express my deep appreciation and sincere gratitude to Ass. Prof. Ahmed Khedr in the Nuc. Safety Eng. Dept. of the Egyptian Nuclear and Radiological Regulatory Authority for his valuable comments, corrections.

\section{REFERENCES}

- Anglart, H. (2010): Thermal-Hydraulics in Nuclear Systems, http://www.diva-portal.org/smash/get/ diva2:500651/fulltext01.pdf

- Anglart , H. (2005): Thermal-Hydraulic Analysis of Single-Phase Flows in Heated Channels , Applied Reactor Technology and Nuclear Power Safety - Lecture 7, Nuclear Reactor Technology Division Department of Energy Technology, KTH, http://www.energy. kth.se/courses/4A1627/Material2005/THPart/07\%20 Single\%20Ph\%20TH\%20Rev\%2001.pdf

- Buongiorno, J. (2010): Notes on Two-Phase Flow, Boiling Heat Transfer, and Boiling Crises in PWRs and BWRs, MIT Department of Nuclear Science and Engineering, JB / Fall. https://ocw.mit.edu/ courses/nuclear-engineering/22-06-engineering-ofnuclear-systems-fall-2010/lectures-and-readings/ MIT22_06F10_lec13.pdf

- Carslaw, H. and Jaeger, J. (1986): Conduction of Heat in Solids, $2^{\text {nd }}$ ed. Clarendon Press.

- de Kruijf, W. (1994): Reactor physics analysis of the Pin-Cell doppler effect in a thermal nuclear reactor, ECN-R-94-033. Technol. Univ. Delft.

- Dittus, F.W. and Boelter, L.M. K. (1985): Heat transfer in automobile radiators of the tubular type. Int. Com. Heat Mass Transfer, 12: 3.

- El-Wakil, M.M. (1978): Nuclear Heat Transport. $1^{\text {st }}$ ed. published by American Nuclear Society.

- Goltsev, A.; Davidenko, V.; Tsibulsky, V. and Lekomtsev, A. (2003): The influence of a nonuniform radial temperature distribution in the fuel on the results of calculation of transients. Ann. Nucl. Energy, 30: 1135 .
- Nikola K. Popov (2015): CHAPTER 6 Thermal-Hydraulic Design, The Essential CANDU, December, http://www.nuceng.ca/candu/pdf/6\%20-\%20Thermalhydraulic\%20Design.pdf.

- Rowlands, G. (1962): Resonance absorption and non-uniform temperature distributions. J. Nucl. Energy, Parts A \& B. Reactor Science and Technology 6(4): doi:10.1016/0368-3230(62)90294-X.

- Tomatis, D. (2013): Heat conduction in nuclear fuel by the Kirchhoff transformation. Ann. Nucl. Energy, 57: 100 .

- Winterton, R. H. S. (1998): Where did the Dittus and Boelter equation come from?. Int. J. Heat Mass Transfer, 41: 809. 


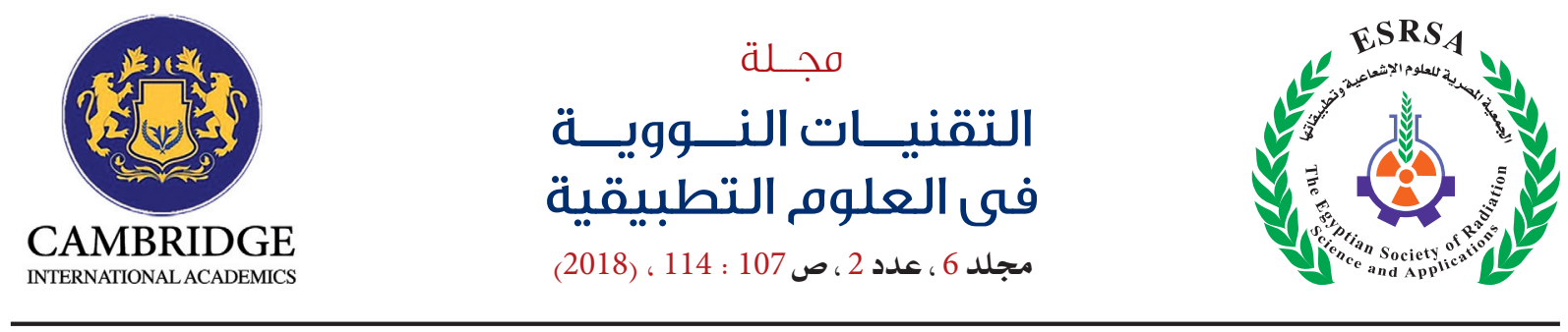

\section{نمذجت السلولك الاستاتيكي الهيدرلوكي الحراري لمفاعلات الماء المضغوط}

إن التحليل الهيدروليكي الحراري للهفاعلات النوويت له أهميت عظمى، نظرا للحاجت إليه

للتنبؤ بتوزيع درجت الحرارة يِّ العناصر الأسـاسيت للمفاعل ، مثل قضبان الوقود وأغلفتها، حيث يتكون قلب مفاعلات الطاقت من عناصر وقود اسطوانيت تحتوي على كريات الوقود وأغلفت الوقود والفرجت التي بينهما. ويهدف البحث إلى حساب توزيع درجت حرارة الوقود وسائل التبريد وتدرج الضغط ِِّ القناة الحارة والمتوسطت وحلدود أمان الأخرى. تقدم هذه الورقت البحثيت برنامـج حسـابي بسيط أحادي الأبعاد بلغتة لفورتران يسهى PWRTH لحساب الحالت الحراريت الهيدروليكيت الثابتت (TH)) والتوصيل الحراري لعناصر الوقود لمفاعلات الماء المضغوط. كما تم اجراء تحليل حدودي للحصول على الحد الأقصى من قدرة المفاعل المحتملت التي تتوافق مـع حدود السـلامتم. 